\title{
Dendritic Core-Shell Macromolecules Soluble in Supercritical Carbon Dioxide
}

Victor Martinez, ${ }^{\dagger}$ Stefan Mecking ${ }^{*},{ }^{\dagger}$ Thierry Tassaing, ${ }^{*}$ Marcel Besnard, ${ }^{*}$ Sandy Moisan, ${ }^{\S}$ François Cansell, ${ }^{\S}$ Cyril Aymonier ${ }^{\S}$

${ }^{\dagger}$ Department of Chemistry, Konstanz University, Universitätsstr. 10, 78457 Konstanz, Germany, ${ }^{\ddagger}$ LPCM, CNRS-UMR 5803, Université Bordeaux 1, 351 cours de la Libération, 33405 Talence Cedex, France,

${ }^{\S}$ ICMCB, CNRS-UPR 9048, Université Bordeaux 1, 87 avenue Albert Schweitzer, 33608 Pessac Cedex, France

\section{Supporting Information}

\section{Materials:}

All the experiments were performed under inert conditions. THF and toluene were dried over Na and used fresh distilled. Hyperbranched polyethyleneimine (PEI) with a DB around $60 \%{ }^{1}$ and a molecular weight around $5 \mathrm{kD}$ were supplied as a water solution ${ }^{2}$. Prior to use water was evaporated under vacuum at $80^{\circ} \mathrm{C}$ for several hours. $2 \mathrm{H}, 2 \mathrm{H}, 3 \mathrm{H}, 3 \mathrm{H}$-perfluoroundecaonoic acid was purchased from Fluorus and Poly(hexafluoropropylene oxide) monocarboxylic acid, chloro terminated from Aldrich. The monocarbonyl acide terminated polydimethylsiloxane and the 3,6,9,12-tetraoxotridecanoic acid were synthesized as described in the literature. ${ }^{3,4}$ Other reagents were commercially available and used without any further purification.

\section{Typical procedure for the synthesis of unimolecular micelles with a hydrophobic shell:}

PEI-NHCOCH $\mathbf{C H}_{2} \mathbf{C}_{\mathbf{8}} \mathbf{F}_{\mathbf{1 7}}, \mathbf{1}$. The $2 \mathrm{H}, 2 \mathrm{H}, 3 \mathrm{H}, 3 \mathrm{H}$-perfluoroundecaonoic acid (1.06g, 2.16mmol) dissolved in THF (10mL) is added slowly to a solution of carbonyldiimidazol $(338 \mathrm{mg}, 2.09 \mathrm{mmol})$ in THF $(10 \mathrm{~mL})$. The reaction is stirred for $1 \mathrm{~h}$ at room temperature. An argon stream is used to displace remaining $\mathrm{CO}_{2}$. Then the mixture is transferred to a schlenk containing the hyperbranched polymer PEI (293mg, $2.09 \mathrm{mmol}$ terminal amino groups). The reaction is heated at $40^{\circ} \mathrm{C}$ over night. The solvent is reduced to $10 \mathrm{~mL}$ and $50 \mathrm{~mL}$ water are added. The white precipitate is isolated and washed with water several times. After drying under high vacuum, the product is obtained as a white powder (480mg, 83\% yield). ${ }^{1} \mathrm{H}$ NMR $\left(\mathrm{C}_{6} \mathrm{~F}_{6}\right) \delta$ ppm: 2.4-3.6 (m, $\mathrm{NCH}_{2} \mathrm{CH}_{2} \mathrm{~N}$ and $\left.\mathrm{R}_{\mathrm{f}} \mathrm{CH}_{2} \mathrm{CH}_{2} \mathrm{CO}\right) .{ }^{13} \mathrm{C} \mathrm{NMR}\left(\mathrm{C}_{6} \mathrm{~F}_{6}\right) \delta$ ppm: 27.2 $\left(\mathrm{R}_{\mathrm{f}} \mathrm{CH}_{2} \mathrm{CH}_{2} \mathrm{CO}\right), 29.0\left(\mathrm{R}_{\mathrm{f}} \mathrm{CH}_{2} \mathrm{CH}_{2} \mathrm{CO}\right), 39\left(\mathrm{NCH}_{2} \mathrm{CH}_{2} \mathrm{NHCO}\right), 50-55\left(\mathrm{NCH}_{2} \mathrm{CH}_{2} \mathrm{~N}\right)$, from 107 to $125\left(\mathrm{CF}_{2}\right), 173.5\left(\mathrm{CH}_{2} \underline{\mathrm{CONHCH}}\right)$. IR: N$\mathrm{H}$ stretch $3306 \mathrm{~cm}^{-1}, \mathrm{C}=\mathrm{O} 1653 \mathrm{~cm}^{-1}, \mathrm{~N}-\mathrm{H}$ bend $1559 \mathrm{~cm}^{-1}$ and secondary amines $1451 \mathrm{~cm}^{-1}$, C-F 1205 and $1149 \mathrm{~cm}^{-1}$.

PEI-NHCOCF ${ }_{2}\left[\mathbf{O C F}_{2} \mathbf{C F}\left(\mathbf{C F}_{3}\right)\right]_{\mathbf{n}} \mathbf{C F}_{2} \mathbf{C l}, 2 .{ }^{1} \mathrm{H}$ NMR $\left(\mathrm{C}_{2} \mathrm{D}_{2} \mathrm{Cl}_{4}\right) \delta$ ppm: 2.4-3.6 (m, NCH $\left.\mathrm{CH}_{2} \mathrm{~N}\right)$. IR: N-H stretch $3294 \mathrm{~cm}^{-1}, \mathrm{C}=\mathrm{O} 1689$ $\mathrm{cm}^{-1}, \mathrm{~N}-\mathrm{H}$ bend 1549 and secondary amines $1454 \mathrm{~cm}^{-1}, \mathrm{C}-\mathrm{F} 1259-1133 \mathrm{~cm}^{-1}$.

PEI-NHCOC ${ }_{15} \mathbf{H}_{30}, 4 .{ }^{1} \mathrm{H}$ NMR $\left(\mathrm{CDCl}_{3}\right)$ Sppm: $0.83\left(\mathrm{t}, 3 \mathrm{H}, \mathrm{CH}_{3}\right), 1.22\left(\mathrm{~m}, 24 \mathrm{H}, \mathrm{CH}_{2}\right), 1.57\left(\mathrm{~m}, 2 \mathrm{H}, \mathrm{COCH}_{2} \mathrm{CH}_{2}\right), 2.11(\mathrm{~m}, 2 \mathrm{H}$, $\left.\mathrm{COCH}_{2} \mathrm{CH}_{2}\right), 2.4-2.8\left(\mathrm{~m}, \mathrm{NCH}_{2} \mathrm{CH}_{2} \mathrm{~N}\right), 3.22\left(\mathrm{~m}, \mathrm{CONHCH}_{2} \mathrm{CH}_{2} \mathrm{~N}\right), 3.6(\mathrm{~m}, \mathrm{NH}) .{ }^{13} \mathrm{C} \mathrm{NMR}\left(\mathrm{CDCl}_{3}\right) \delta \mathrm{ppm}: 14.3\left(\mathrm{CH}_{3}\right), 22.9,29.6,29.9$ and $32.1\left(\mathrm{CH}_{2}\right), 26.2\left(\mathrm{COCH}_{2} \underline{\mathrm{CH}}_{2}\right), 36.7\left(\mathrm{COCH}_{2} \mathrm{CH}_{2}\right), 33$ and $38\left(\mathrm{CONHCH}_{2} \mathrm{CH}_{2} \mathrm{~N}\right), 47.4,49.0,52.8$ and $53.7\left(\mathrm{NCH}_{2} \mathrm{CH}_{2} \mathrm{~N}\right), 174.0$ $\left(\mathrm{CH}_{2} \mathrm{CONHCH}_{2}\right)$. IR: $\mathrm{C}=\mathrm{O} 1645 \mathrm{~cm}^{-1}$.

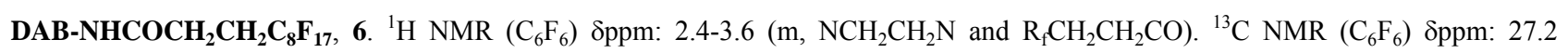
$\left(\mathrm{R}_{\mathrm{f}} \mathrm{CH}_{2} \underline{\mathrm{CH}}_{2} \mathrm{CO}\right), 29.0\left(\mathrm{R}_{\mathrm{f}} \mathrm{CH}_{2} \mathrm{CH}_{2} \mathrm{CO}\right), 39\left(\mathrm{NCH}_{2} \underline{\mathrm{CH}}_{2} \mathrm{NHCO}\right), 50-55\left(\mathrm{NCH}_{2} \mathrm{CH}_{2} \mathrm{~N}\right), 107-125\left(\mathrm{CF}_{2}\right), 171.7\left(\mathrm{CH}_{2} \mathrm{CONHCH}_{2}\right) . \mathrm{IR}: \mathrm{N}-\mathrm{H}$ stretch $3303 \mathrm{~cm}^{-1}, \mathrm{C}=\mathrm{O} 1650 \mathrm{~cm}^{-1}$, N-H bend $1563 \mathrm{~cm}^{-1}$, C-F 1204, 1149 and $1112 \mathrm{~cm}^{-1}$. 
PEI-NHCO-p- $\left(\mathrm{C}_{6} \mathrm{H}_{4}\right)-\mathbf{O C H}_{2} \mathbf{C H}_{2} \mathrm{CH}_{2} \mathrm{Si}(\mathrm{Me})_{2}\left[\left(-\mathrm{OSi}(\mathrm{Me})_{2}\right]_{n} \mathbf{C H}_{2} \mathbf{C H}_{2} \mathrm{SiMe}_{3}\right.$, 3. Allyl bromide (8.5mL, 96.3mmol) were added to solution of $p$-hydroxybenzylbenzoate $(20 \mathrm{~g}, 87.6 \mathrm{mmol})$ and potassium carbonate $(12 \mathrm{~g}, 87.6 \mathrm{mmol})$ in acetone $100 \mathrm{~mL}$. Reaction was

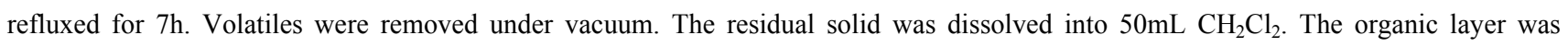
washed with basic an neutral water, dried over $\mathrm{Na}_{2} \mathrm{SO}_{4}$ and filtered. After solvent evaporation, an oil was obtained. Purification was achieved through a silica-gel column using $\mathrm{CH}_{2} \mathrm{Cl}_{2}$-hexane 1:1 as eluent. Product was obtained as a white solid. ${ }^{1} \mathrm{H} \mathrm{NMR}\left(\mathrm{CDCl}_{3}\right) \delta \mathrm{ppm}$ :

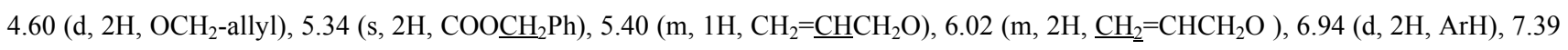
$(\mathrm{m}, 5 \mathrm{H}, \mathrm{COO}-\underline{\mathrm{Ph}})$ and $8.04(\mathrm{~d}, 2 \mathrm{H}, \mathrm{ArH}) .{ }^{13} \mathrm{C} \mathrm{NMR}\left(\mathrm{CDCl}_{3}\right) \delta \mathrm{ppm}$ : $68.1\left(\mathrm{COOCH}_{2} \mathrm{Ph}\right), 70.6\left(\mathrm{OCH}_{2} \mathrm{Allyl}\right), 116.0\left(\underline{\mathrm{CH}}_{2}=\mathrm{CHCH}{ }_{2} \mathrm{O}\right), 134.3$ $\left(\mathrm{CH}_{2}=\mathrm{CHCH}_{2} \mathrm{O}\right), 164.1,119.9,129.8$ and $124.4(\mathrm{OArCOO}), 138.0,129.8$ and $133.5\left(\mathrm{COOCH}_{2} \mathrm{Ph}\right), 167.9(\mathrm{C}=\mathrm{O}) . \mathrm{IR}: \mathrm{C}=\mathrm{O} 1710 \mathrm{~cm}^{-1}$. This polydimethylsiloxane hydride-terminated $(12.5 \mathrm{~g}, 40 \mathrm{eq})$, -allyloxybenzylbenzoate $(4.2 \mathrm{~g}, 16 \mathrm{mmol})$ vinyltrimethylsilane $(3.7 \mathrm{~mL}, 24 \mathrm{mmol})$ and toluene $5 \mathrm{~mL}$ were introduced into a rota-flo flask. After purging with argon, cyclovinylmethylsiloxan-platinium complex $(18 \mu \mathrm{L}$ catalyst PC085) was added and the reaction mixture was heated at $40^{\circ} \mathrm{C}$ for 4 days ( $\mathrm{Si}-\mathrm{H} 2125 \mathrm{~cm}^{-1}$ IR band was disappeared). Volatiles were removed under vacuum. The monoester product was isolated by a silica gel column chromatography with $\mathrm{CH}_{2} \mathrm{Cl}_{2}$-pentane $1: 20$ as eluent. Isolated product 5.3g, yield 33\%. ${ }^{1} \mathrm{H} \mathrm{NMR}\left(\mathrm{CDCl}_{3}\right) \delta \mathrm{ppm}:-0.02\left(\mathrm{~s}, 9 \mathrm{H}, \mathrm{CH}_{2} \mathrm{Si}\left(\underline{\mathrm{CH}}_{3}\right)_{3}\right), 0.00\left(\mathrm{~s}, 6 \mathrm{H}, \mathrm{CH}_{2} \mathrm{Si}\left(\mathrm{CH}_{3}\right)_{2} \mathrm{O}\right), 0.08(\mathrm{~m}, 54 \mathrm{H}$, $\left.\mathrm{OSi}\left(\mathrm{CH}_{2}\right)_{2} \mathrm{O}\right), 0.41$ (d, 4H, $\left.\mathrm{SiCH}_{2} \mathrm{CH}_{2} \mathrm{Si}\right), 0.66$ (m, $\left.2 \mathrm{H}, \mathrm{SiCH}_{2} \mathrm{CH}_{2} \mathrm{CH}_{2}\right), 1.84$ (m, 2H, $\left.\mathrm{SiCH}_{2} \underline{\mathrm{CH}}_{2} \mathrm{CH}_{2}\right), 3.97$ (t, 2H, $\left.\mathrm{CH}_{2} \mathrm{CH}_{2} \underline{\mathrm{CH}}_{2} \mathrm{O}\right), 5.34(\mathrm{~s}$, $2 \mathrm{H}, \mathrm{COOCH} 2 \mathrm{Ph}), 6.94(\mathrm{~d}, 2 \mathrm{H}, \mathrm{ArH}), 7.39(\mathrm{~m}, 5 \mathrm{H}, \mathrm{COO}-\underline{\mathrm{Ph}})$ and $8.04(\mathrm{~d}, 2 \mathrm{H}, \mathrm{ArH}) .{ }^{13} \mathrm{C} \mathrm{NMR}_{2}\left(\mathrm{CDCl}_{3}\right) \delta \mathrm{ppm}:-2.2\left(\mathrm{Si}\left(\mathrm{CH}_{3}\right)_{3}\right),-0.5$

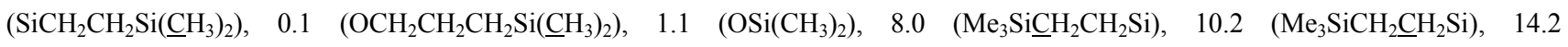
$\left(\mathrm{OCH}_{2} \mathrm{CH}_{2} \mathrm{CH}_{2} \mathrm{Si}\right), 23.1\left(\mathrm{OCH}_{2} \underline{\mathrm{CH}}_{2} \mathrm{CH}_{2} \mathrm{Si}\right), 70.7\left(\mathrm{OCH}_{2} \mathrm{CH}_{2} \mathrm{CH}_{2} \mathrm{Si}\right), 68.1\left(\mathrm{COOCH}_{2} \mathrm{Ph}\right), 164.1,119.9,129.8$ and $124.4(\mathrm{O} \underline{\mathrm{ACOO}}), 138.0$, 129.8 and $133.5\left(\mathrm{COOCH}_{2} \mathrm{Ph}\right), 167.9(\mathrm{C}=\mathrm{O})$. IR: $\mathrm{C}=\mathrm{O} 1710 \mathrm{~cm}^{-1}$, Si-O 1165, 1025 and $789 \mathrm{~cm}^{-1}$. In a round bottom flask this monoester and $\mathrm{Pd} / \mathrm{C}(10 \%, 500 \mathrm{mg})$ were purged with argon. Then degassed EtOH $16 \mathrm{~mL}$, THF $86 \mathrm{~mL}$ and cyclohexene $(0.4 \mathrm{~mL}, 3.7 \mathrm{mmol})$ were added. The reaction was stirred at reflux during 4 days. After filtration over celite, solvent was removed yielding a colourless oil. The white precipitate formed by addition of water was isolated and washed several times with water. Purification through a silica-gel column with THF yields the deprotected acid. Isolated product $3.9 \mathrm{~g}$ yield $74 \%$. ${ }^{1} \mathrm{H} \mathrm{NMR}\left(\mathrm{CDCl}_{3}\right) \delta \mathrm{ppm}:-0.02\left(\mathrm{~s}, 9 \mathrm{H}, \mathrm{CH}_{2} \mathrm{Si}\left(\underline{\mathrm{CH}}_{3}\right)_{3}\right), 0.00(\mathrm{~s}, 6 \mathrm{H}$, $\left.\mathrm{CH}_{2} \mathrm{Si}\left(\underline{\mathrm{CH}}_{3}\right)_{2} \mathrm{O}\right), 0.08\left(\mathrm{~m}, 54 \mathrm{H}, \mathrm{OSi}\left(\mathrm{CH}_{2}\right)_{2} \mathrm{O}\right), 0.41$ (d, 4H, SiCH $\left.\mathrm{CH}_{2} \mathrm{Si}\right), 0.66\left(\mathrm{~m}, 2 \mathrm{H}, \mathrm{SiCH}_{2} \mathrm{CH}_{2} \mathrm{CH}_{2}\right), 1.84\left(\mathrm{~m}, 2 \mathrm{H}, \mathrm{SiCH}_{2} \mathrm{CH}_{2} \mathrm{CH}_{2}\right)$, $3.97\left(\mathrm{t}, 2 \mathrm{H}, \mathrm{CH}_{2} \mathrm{CH}_{2} \mathrm{CH}_{2} \mathrm{O}\right), 6.94(\mathrm{~d}, 2 \mathrm{H}, \mathrm{ArH})$, and $8.04(\mathrm{~d}, 2 \mathrm{H}, \mathrm{ArH}) .{ }^{13} \mathrm{C} \mathrm{NMR}\left(\mathrm{CDCl}_{3}\right) \delta \mathrm{ppm}:-2.2\left(\mathrm{Si}\left(\mathrm{CH}_{3}\right)_{3}\right),-0.5$ $\left(\mathrm{SiCH}_{2} \mathrm{CH}_{2} \mathrm{Si}\left(\underline{\mathrm{CH}}_{3}\right)_{2}\right), \quad 0.1 \quad\left(\mathrm{OCH}_{2} \mathrm{CH}_{2} \mathrm{CH}_{2} \mathrm{Si}\left(\underline{\mathrm{CH}}_{3}\right)_{2}\right), \quad 1.1 \quad\left(\mathrm{OSi}\left(\mathrm{CH}_{3}\right)_{2}\right), \quad 8.0 \quad\left(\mathrm{Me}_{3} \mathrm{SiCH}_{2} \mathrm{CH}_{2} \mathrm{Si}\right), \quad 10.2 \quad\left(\mathrm{Me}_{3} \mathrm{SiCH}_{2} \mathrm{CH}_{2} \mathrm{Si}\right), \quad 14.2$ $\left(\mathrm{OCH}_{2} \mathrm{CH}_{2} \underline{\mathrm{CH}}_{2} \mathrm{Si}\right), 23.1\left(\mathrm{OCH}_{2} \underline{\mathrm{CH}}_{2} \mathrm{CH}_{2} \mathrm{Si}\right), 70.7\left(\mathrm{O}_{\underline{C}} \mathrm{CH}_{2} \mathrm{CH}_{2} \mathrm{Si}\right), 163.7,114.2,132.3$ and $121.3(\mathrm{O} \underline{\operatorname{ArCOO}}), 171.3(\mathrm{C}=\mathrm{O}) . \mathrm{IR}: \mathrm{C}=\mathrm{O}$ $1696 \mathrm{~cm}^{-1}$, Si-O 1165,1025 and $789 \mathrm{~cm}^{-1}$. carbonyldiimidazol $(338 \mathrm{mg}, 2.09 \mathrm{mmol})$ was added slowly to a solution of the above obtained PDMS monocarbonyl acid-terminated $(1851 \mathrm{mg}, 2.16 \mathrm{mmol})$ in $20 \mathrm{~mL}$ THF. The reaction evolution was observed through $\mathrm{CO}_{2}$ formation. After stirring at room temperature during $2 \mathrm{~h}$, the solution was degassed by an argon stream. PEI (293mg, 2.09mmol primary amines) was dissolved into $20 \mathrm{~mL}$ THF at $40^{\circ} \mathrm{C}$ and added to the reaction mixture. Reaction was allowed to stir at $50^{\circ} \mathrm{C}$ over night. $50 \mathrm{~mL}$ water were added to induce a complete product precipitation. Upon cooling to room temperature, solvent was removed. The white precipitate was dissolved in toluene and washed with water. Then solvent was evaporated to give a white solid. After cleaning with a methanol solution saturated in $\mathrm{K}_{2} \mathrm{CO}_{3}$ and pure methanol, the solid was dried under vacuum. Isolated product $1897 \mathrm{mg}$, yield $90 \% .{ }^{1} \mathrm{H} \mathrm{NMR}\left(\mathrm{CDCl}_{3}\right)$ 8ppm: 0.02 (s, 9H, $\left.\mathrm{CH}_{2} \mathrm{Si}\left(\underline{\mathrm{CH}}_{3}\right)_{3}\right), 0.00$ (s, 6H, CH $\left.\mathrm{CH}_{2} \mathrm{Si}\left(\underline{\mathrm{CH}}_{3}\right)_{2} \mathrm{O}\right), 0.08$ (m, 54H, OSi $\left.\left(\mathrm{CH}_{2}\right)_{2} \mathrm{O}\right), 0.41$ (d, 4H, $\left.\mathrm{SiCH}_{2} \mathrm{CH}_{2} \mathrm{Si}\right), 0.66(\mathrm{~m}, 2 \mathrm{H}$, $\left.\mathrm{SiCH} \mathrm{CH}_{2} \mathrm{CH}_{2}\right), 1.84\left(\mathrm{~m}, 2 \mathrm{H}, \mathrm{SiCH}_{2} \mathrm{CH}_{2} \mathrm{CH}_{2}\right), 2.4-2.8\left(\mathrm{~m}, \mathrm{NCH}_{2} \mathrm{CH}_{2} \mathrm{~N}\right), 3.22\left(\mathrm{~m}, \mathrm{CONCH}_{2} \mathrm{CH}_{2} \mathrm{~N}\right), 3.97\left(\mathrm{t}, 2 \mathrm{H}, \mathrm{CH}_{2} \mathrm{CH}_{2} \mathrm{CH}_{2} \mathrm{O}\right), 6.94(\mathrm{~d}$, $2 \mathrm{H}, \mathrm{ArH})$, and $8.04(\mathrm{~d}, 2 \mathrm{H}, \mathrm{ArH}) .{ }^{13} \mathrm{C} \mathrm{NMR}\left(\mathrm{CDCl}_{3}\right)$ 8ppm: -2.2 $\left(\mathrm{Si}\left(\mathrm{CH}_{3}\right)_{3}\right),-0.5\left(\mathrm{SiCH}_{2} \mathrm{CH}_{2} \mathrm{Si}\left(\underline{\mathrm{CH}}_{3}\right)_{2}\right), 0.1\left(\mathrm{CH}_{2} \mathrm{CH}_{2} \mathrm{CH}_{2} \mathrm{Si}\left(\underline{\mathrm{CH}}_{3}\right)_{2}\right), 1.1$ $\left(\mathrm{OSi}\left(\mathrm{CH}_{3}\right)_{2}\right), 8.0\left(\mathrm{Me}_{3} \mathrm{SiCH}_{2} \mathrm{CH}_{2} \mathrm{Si}\right), 10.2\left(\mathrm{Me}_{3} \mathrm{SiCH}_{2} \underline{\mathrm{CH}}_{2} \mathrm{Si}\right), 14.2\left(\mathrm{OCH}_{2} \mathrm{CH}_{2} \underline{\mathrm{C}} \mathrm{H}_{2} \mathrm{Si}\right), 23.1\left(\mathrm{OCH}_{2} \underline{\mathrm{CH}}_{2} \mathrm{CH}_{2} \mathrm{Si}\right), 39\left(\mathrm{CONH}_{2} \mathrm{H}_{2} \mathrm{CH}_{2} \mathrm{~N}\right), 47$, 49, 52 and $54\left(\mathrm{NCH}_{2} \mathrm{CH}_{2} \mathrm{~N}\right), 70.5\left(\mathrm{OCH}_{2} \mathrm{CH}_{2} \mathrm{CH}_{2} \mathrm{Si}\right), 161.5,114.0,128.9$ and $126.5(\mathrm{O} \underline{\operatorname{ArCOO}}), 161.5(\operatorname{ArCONHCH})$. IR: $\mathrm{C}=\mathrm{O}_{1696 \mathrm{~cm}^{-}}$ ${ }^{1}$, Si-O 1165, 1025 and $789 \mathrm{~cm}^{-1}$. Anal. Calcd. for $\mathrm{C}_{1310} \mathrm{H}_{3016} \mathrm{~N}_{116} \mathrm{O}_{348} \mathrm{Si}_{313}$ : C, 45.27; H, 8.57; N, 4.67. Found: C, 46.29; H, 8.83; N, 5.62. 
PEI-NHCOPEGMe, 5. Tetraethylenglycol monomethylether (2.08g, 0.01mol), potassium hydroxide (1.12g, 0.02mol) and potassium permanganate $(3.16 \mathrm{~g}, 0.02 \mathrm{~mol})$ in $100 \mathrm{~mL}$ water are stirred at room temperature during $12 \mathrm{~h}$. The brown precipitate is filtered off and washed several times with water. After reduction of the aqueous volume to $50 \mathrm{~mL}$, the product is extracted with dichloromethane. The organic solution is dried over $\mathrm{Na}_{2} \mathrm{SO}_{4}$ and filtered. The solvent is evaporated yielding the 3,6,9,12-tetraoxatridecanoic acid as an oil (1.4g, $63 \%$ yield). This oil $(1.22 \mathrm{~g}, 5.5 \mathrm{mmol})$ dissolved in THF $(25 \mathrm{~mL})$ is added slowly to a solution of carbonyldiimidazol $(842 \mathrm{mg}, 5.2 \mathrm{mmol})$ in THF $(25 \mathrm{~mL})$. The reaction is stirred for $1 \mathrm{~h}$ at room temperature. An argon stream is used to displace remaining $\mathrm{CO}_{2}$. Then the mixture is transferred to a schlenk containing the hyperbranched polymer PEI ( $745 \mathrm{mg}, 5.2 \mathrm{mmol}$ terminal amino groups). The reaction is heated at $40^{\circ} \mathrm{C}$ over night. The solvent is evaporated and the product is purified by dialysis in water $(1.4 \mathrm{~g}, 80 \%$ yield $) .{ }^{1} \mathrm{H} \mathrm{NMR}\left(\mathrm{CDCl}_{3}\right) \delta \mathrm{ppm}: 2.4-$ $2.8\left(\mathrm{~m}, \mathrm{NCH}_{2} \mathrm{CH}_{2} \mathrm{~N}\right), 3.33\left(\mathrm{~s}, 3 \mathrm{H}, \mathrm{OCH}_{3}\right), 3.6\left(\mathrm{~m}, 12 \mathrm{H}, \mathrm{OCH}_{2} \mathrm{CH}_{2} \mathrm{O}\right), 3.94\left(\mathrm{~m}, 2 \mathrm{H}, \mathrm{COCH}_{2} \mathrm{O}\right) .{ }^{13} \mathrm{C} \mathrm{NMR}\left(\mathrm{CDCl}_{3}\right) \delta \mathrm{ppm}: 59.2\left(\mathrm{CH}_{3}\right), 70-$

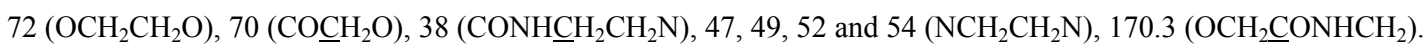

\section{Solubility measurements:}

The infrared absorption experiments were performed using a homemade titanium optical cell ${ }^{5}$ withstanding high pressures up to $35 \mathrm{MPa}$ and temperatures up to $250^{\circ} \mathrm{C}$. A schematic view of the optical cell is shown in Figure S1. Optical access is given by the way of four cylindrical windows, two silicon windows for the infrared absorption measurements with a path length of $2.5 \mathrm{~cm}$ (which can be varied from 0.3 to $2.5 \mathrm{~cm}$ ) and the two others sapphire windows for direct observation of the solution to insure that there is no demixing in the sample. The cell volume is $5.5 \mathrm{~cm}^{3}$ and the homogeneity is ensured with a magnetic stirrer disposed at the bottom of the cell. The sealing is obtained using the unsupported area principle. All windows are positioned on the flat surface of the Inconel plug with a $100 \mu \mathrm{m}$ kapton foil placed between the window and the plug in order to compensate for imperfections at the two surfaces. Flat teflon seals are used to insure sealing between the plug and the cell body. The heating is performed with four cartridge heaters disposed in the body of the cell in which two thermocouples are placed. The first one is located close to one cartridge in order to achieve a good temperature regulation and the second one is kept close to the sample area, to measure the temperature with an accuracy of about $\Delta \mathrm{T} \sim \pm 0.5^{\circ} \mathrm{C}$. The cell is connected via a stainless steel capillary to a hydraulic pressurising system which allows to adjust the pressure up to $50 \mathrm{MPa}$ with an absolute uncertainty of $\pm 0.1 \mathrm{MPa}$ with a relative error of $\pm 0.3 \%$ (Figure S2).

a)

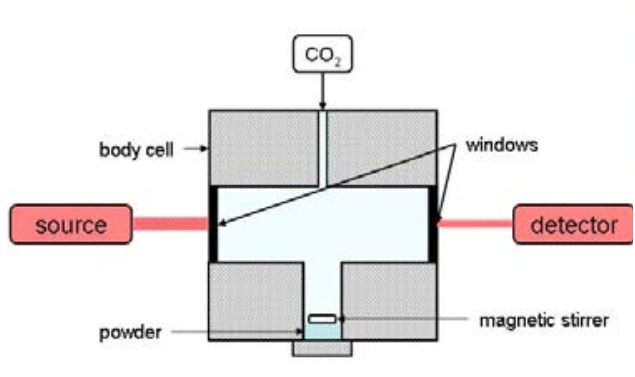

Figure S1: a) Scheme of the high pressure high temperature cell; b) Experimental set-up b)

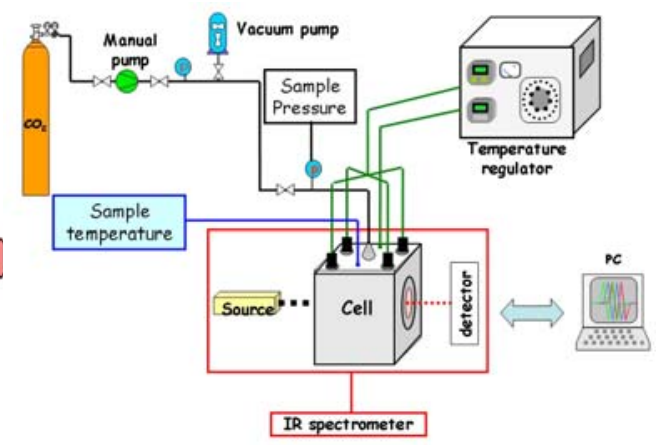


The infrared absorption measurements are performed with a Biorad interferometer (type FTS-60A). Single beam spectra recorded in the spectral range $400-6000 \mathrm{~cm}^{-1}$ with $2 \mathrm{~cm}^{-1}$ resolution are obtained by Fourier transformation of 50 accumulated interferograms. The spectra have been collected at two different constant temperatures, $40^{\circ} \mathrm{C}$ and $100^{\circ} \mathrm{C}$, as a function of pressure, from 6 to $35 \mathrm{MPa}$. A typical infrared spectrum, as they appear after the removal of the $\mathrm{CO}_{2}$ contribution, is displayed in Figure $\mathrm{S} 2$. Then, after identification of specific vibrational modes associated with functional groups of the solute, the integrated intensity of these characteristic infrared bands allows to determine the concentration of the solute in solution according to Beer-Lambert law, $\mathbf{A}=\boldsymbol{\varepsilon} . \mathbf{l}$. c with A, sample absorbance without dimension; $\varepsilon$, molar extinction coefficient $\left(\mathrm{L} \mathrm{mol}^{-1} \mathrm{~cm}^{-1}\right) ; 1$, optical path length $(\mathrm{cm})$ and c, sample concentration $\left(\mathrm{mol} \mathrm{L}^{-1}\right)$. In this study, a spectral domain is integrated to determine A which implies that $\varepsilon$ is homogeneous to $\mathrm{L} \mathrm{mol}^{-1} \mathrm{~cm}^{-2}$. Therefore, the method of solubility determination that we adopted is the following: i) identification of a characteristic vibrational band; ii) determination of the molar extinction coefficient for the considered bands, by checking that a small quantity of the product is completely solubilized at $40^{\circ} \mathrm{C}$ and 35 $\operatorname{MPa}\left(\rho=0.9 \mathrm{~g} \mathrm{~cm}^{-3}\right)$ (see Table S1); iii) determination of the solubility with an important initial mass of product by integrating the selected bands.



Figure S2: Spectrum of PEI-NHCOCH${ }_{2} \mathrm{CH}_{2} \mathrm{C}_{8} \mathrm{~F}_{17}, \mathbf{1}\left(\mathrm{T}=40^{\circ} \mathrm{C}, \mathrm{P}=25 \mathrm{MPa}\right)$.

Table S1. Molar Extinction Coefficients $\left(10^{-2} \mathrm{~L} \mathrm{~mol}^{-1} \mathrm{~cm}^{-2}\right)$ and corresponding region $\left(\mathrm{cm}^{-1}\right)$

\begin{tabular}{|c|c|c|c|}
\hline Entry & Formula & $\begin{array}{l}\text { Vibrational } \\
\text { band }\end{array}$ & $\begin{array}{c}\text { Molar Extinction } \\
\text { Coefficients (region) }\end{array}$ \\
\hline 1 & PEI -CO- $\mathrm{C}_{10} \mathrm{H}_{4} \mathrm{~F}_{17}$ & $\begin{array}{l}\mathrm{C}-\mathrm{F} \\
\mathrm{C}=\mathrm{O}\end{array}$ & $\begin{array}{l}1931(1123-1163) \\
3891(1634-1708)\end{array}$ \\
\hline 2 & PEI -CO- $\mathrm{C}_{10} \mathrm{ClF}_{20} \mathrm{O}_{3}$ & $\begin{array}{l}\mathrm{C}-\mathrm{F} \\
\mathrm{C}=\mathrm{O}\end{array}$ & $\begin{array}{ll}385 & (943-1016) \\
800 & (1655-1749)\end{array}$ \\
\hline 3 & PEI -CO- $\mathrm{C}_{31} \mathrm{H}_{74} \mathrm{O}_{8} \mathrm{Si}_{9}$ & $\begin{array}{l}\mathrm{Si}-\mathrm{O}-\mathrm{Si} \\
\mathrm{C}-\mathrm{H}\end{array}$ & $\begin{array}{l}29490(970-1152) \\
1547 \quad(2943-2983)\end{array}$ \\
\hline 4 & PEI -CO- $\mathrm{C}_{10} \mathrm{H}_{21}$ & & insoluble \\
\hline 5 & PEI -CO- $\mathrm{C}_{8} \mathrm{H}_{17} \mathrm{O}_{4}$ & & insoluble \\
\hline 6 & DAB-CO- $\mathrm{C}_{10} \mathrm{H}_{4} \mathrm{~F}_{17}$ & $\begin{array}{l}\mathrm{C}-\mathrm{F} \\
\mathrm{C}=\mathrm{O}\end{array}$ & $\begin{array}{l}1512(1123-1163) \\
2731\end{array}$ \\
\hline
\end{tabular}

(1) $\mathrm{DB}=2 \mathrm{D} /(2 \mathrm{D}+\mathrm{L}), \mathrm{D}=$ dendritic units (tertiary amines), $\mathrm{L}=$ linear units (secondary amines).

(2) LUPASOL $® P R O D U C T$ RANGE, Preliminary Technical Information, BASF.

(3) Abed, S. ; Boileau, S. ; Bouteiller, L. Macromolecules 2000, 33, 8479-8487.

(4) Vögtle F. Liebigs Ann. Chem. 1980, 858-862.

(5) Rey, S.; Bordeaux I: Bordeaux, 1999. 